\title{
The Effect of Perceived Organizational Support and Job satisfaction on Organizational Citizenship Behavior
}

\author{
Muthia Roza Linda ${ }^{1}$, Riza Yonita ${ }^{2}$, Engla Desnim Silvia ${ }^{3}$ \\ ${ }^{1}$ Universitas Negeri Padang, Padang, Indonesia, $\triangle$ muthia_rozalinda@yahoo.com \\ 2 Universitas Putra Indonesia "YPTK", Padang, Indonesia, $\triangle$ zheanita99@gmail.com \\ 2 Universitas Putra Indonesia "YPTK", Padang, Indonesia, $\square$ engladesnim1986@gmail.com
}

\begin{abstract}
This study aims to analyze: 1) how the effect of perceived organizational support on organizational citizenship behavior of BPAD employees in West Pasaman Regency; and 2) how the effect of job satisfaction on organizational citizenship behavior of BPAD employees in West Pasaman Regency. This study is causative research which aims to see to what extent the independent variables influence the dependent variable. The population in this study was the employees of the Regional Revenue and Asset Agency of West Pasaman Regency, with a total sample of 80 employees. The data were analyzed using multiple linear regression with IBM SPSS version 24. The results showed that: 1) perceived organizational support had negative effect but not significant on organizational citizenship behavior of BPAD employees in West Pasaman Regency; and 2) job satisfaction had positive and significant effect on organizational citizenship behavior of BPAD employees in West Pasaman Regency. R square value was 0.530 which means that both independent variables simultaneously influenced the dependent variable in this study as much as $21.2 \%$, while the other $78.9 \%$ was influenced by other factors not examined in this study.
\end{abstract}

Keywords: perceived organizational support, job satisfaction, perceived organizational support

\section{Introduction}

Employees or human resources are the most important aspects in a company; therefore, they must be managed, directed, mobilized and nurtured properly in order that they can carry out their duties and functions as expected and the company's goals can be achieved. To achieve company goals, employees are expected to behave in accordance with company expectations. Basically when employees carry out formal tasks in accordance with the job description, the employees can be said to have good performance, because they have shown the behavior that is in accordance with the expectations of the organization.

The behavior that is in accordance with the expectations of the organization is also called in-role behavior. In addition to in-role behavior, employees are also expected to have extra-role behavior. Extra-role behavior is work behavior that is not part of the employee's formal job description but it is highly appreciated if it is performed because it increases the effectiveness and sustainability of the organization (Katz, in Purba and Seniati, 2004). Extra-role behavior in a company is also known as Organizational Citizenship Behavior (OCB). Greenberg and Baron (2003) define Organizational Citizenship Behavior as a form of someone's informal behavior outside the formal behavior expected to contribute to the goodness of the organization and what is in it.

According to Mariman (2014) in the era of bureaucratic reform as currently being carried out in various government institutions, the role of $\mathrm{OCB}$ is considered vital and greatly determines organization performance. Aside from being a unique element of unique behavior in the world of work, OCB is also an aspect that is almost uncommon within the scope of government apparatus. It is because OCB is an individual characteristic that not only includes the ability and willingness to do the main tasks but also wants to do extra tasks such as having the desire to cooperate with other employees, feeling like to help, giving advice, participating actively, providing extra services to service users, and using their working time effectively. 
Employees' OCB behavior is hardly and rarely found in public institutions. Although it is still considered rare and rarely encountered, the emergence of OCB has become a positive thing for public agencies including the Regional Revenue and Asset Agency (BPAD) of West Pasaman Regency. Regional Revenue and Asset Agency (BPAD) of West Pasaman Regency is the spearhead in the implementation of the Regional Government; both main tasks and co-administration tasks must be balanced by the Regional Original Income (PAD). With the emergence of OCB behavior from self-will of BPAD employees, it will be a positive thing for the public institution.

In this study, the researchers had conducted a pre-survey at BPAD, West Pasaman Regency. Based on the pre-survey results, it was seen that the implementation of organizational citizenship behavior of BPAD employees in West Pasaman Regency was still low. The researchers discovered various phenomena related to organizational citizenship behavior at BPAD, West Pasaman Regency. Altruism (mutual help behavior) of BPAD employees in West Pasaman Regency, that was the behavior of helping colleagues voluntarily, was still lacking. Colleagues would only help if asked for help.

Then, in terms of courtesy of BPAD employees in West Pasaman Regency, some employees in certain parts of the office were seen leaving the office even though it was still work hours. This was very contrary to office regulations and it was one example of violations of the office rules.

The next one is in terms of sportsmanship (positive attitude) of BPAD employees in West Pasaman Regency. When there was much urgent work to do and the chief assigned the employees to work beyond office hours even beyond working days, such as on Saturday and Sunday, some employees did not come to work. They were motivated to work if they were rewarded by their chief.

An organization can improve the implementation of organizational citizenship behavior of its employees by concerning the factors that influence it, one of which is perceived organizational support (POS). Perceived Organizational Support (POS) refers to employees' perceptions of the extent to which an organization evaluates their contribution and cares about their welfare (Eisenberger and Rhoades, 2001). The employee with higher level of perceived organizational support will make them feel more obliged to help the organization achieve its goals (Eisenberger et al 2001). Based on reciprocity norm, organizational support theory shows that the employees who believe they receive a higher level of support from the organization will show extra-role behavior better, they feel obliged to care about the organization and help fulfill its goals through positive attitude and behavior towards the organization (Eisenberger et al 2001).

Then, the other factor that influences organizational citizenship behavior is job satisfaction. There are a number of studies that state that job satisfaction can mediate the relationship between perceived organizational support and organizational citizenship behavior. One of the studies that states this relationship is a study conducted by Novira and Martono (2015). According to Novira and Martono (2015) high perceived organizational support will increase employees' job satisfaction and they will try to do things that are beneficial for the organization in this case namely organizational citizenship behavior.

Robbins and Judge (2008) state that job satisfaction influences Organizational Citizenship Behavior. When employees are satisfied with their work, these employees tend to talk positively about the organization, help other individuals, and exceed normal expectations in their work. Basically, job satisfaction is a positive feeling about someone's work which is the result of evaluating the characteristics (Robbins and Judge, 2008).

Based on the described above, The hypothesis of this research are:

H1: Perceived Organizational Support has positive effect on Organizational Citizenship Behavior of BPAD employees in West Pasaman Regency.

H2: Job satisfaction has positive effect on Organizational Citizenship Behavior of BPAD employees in West Pasaman Regency. 


\section{Methods}

The research design used in this study is causative research. Sugiyono (2012) says that causative research is the research that states causal relationships (causative). This study was conducted at BPAD in West Pasaman Regency, starting from November 2018 to March 2019 when the study was completed. The population of this study was all of BPAD employees in West Pasaman Regency. The number of employees working at BPAD in West Pasaman Regency was 88 employees consisting of civil servants and contract employees. Because the number of population was less than 100 people, the overall population was used as sample which means that the researchers used a census sampling technique and the entire population became the respondents. According to Arikunto (2002) if the population is less than 100 people, then the entire population will be taken as samples. The research data were obtained through the distribution of questionnaires to respondents, which were related to research variables and taken directly. The collected data were then analyzed using a multiple linear regression analysis approach by the help of SPSS Application Version 24.

\section{Operational Definition of Variables}

To provide the explanation of the research variables used, the following are the operational definition of each variable in this study:

Table 1 Operational Definition of Research Variables

\begin{tabular}{|c|c|c|c|}
\hline No. & Variable & Conseptual Definition & Indicator \\
\hline 1. & $\begin{array}{l}\text { Organizational } \\
\text { Citizenship Behavior }\end{array}$ & $\begin{array}{l}\text { Selected behavior that is not } \\
\text { part of the employee's work } \\
\text { obligations, but it supports } \\
\text { the functioning of the } \\
\text { organization effectively. } \\
\text { Robbins and Judge (2008) }\end{array}$ & $\begin{array}{l}\text { 1. Altruism } \\
\text { 2. Courtesy } \\
\text { 3. Sportsmanship } \\
\text { 4. Conscientiousness } \\
\text { 5. Civic virtue } \\
\text { Organ in I Gusti Ayu et al (2011) } \\
\end{array}$ \\
\hline 2. & $\begin{array}{l}\text { Perceived } \\
\text { Organizational } \\
\text { Support }\end{array}$ & $\begin{array}{l}\text { Perceived organizational } \\
\text { support refers to employee } \\
\text { perceptions of the extent to } \\
\text { which the organization } \\
\text { evaluates employee } \\
\text { contributions and cares about } \\
\text { employee welfare. } \\
\text { Rhoades \& Eisenberger (2002) }\end{array}$ & $\begin{array}{l}\text { 1. The organization appreciates } \\
\text { the employee contributions. } \\
\text { 2. The organization appreciates } \\
\text { the extra effort that the } \\
\text { employee has given. } \\
\text { 3. Organization pays attention } \\
\text { to all employee complaints. } \\
\text { 4. Organization is very } \\
\text { concerned about employee } \\
\text { welfare. } \\
\text { 5. The organization will help } \\
\text { employees if they do not do a } \\
\text { good job. } \\
\text { 6. Organization cares about } \\
\text { general satisfaction with the } \\
\text { work of employees. } \\
\text { 7. Organization shows great } \\
\text { attention to employees. } \\
\text { 8. Organization feels proud of } \\
\text { the success of the employees } \\
\text { at work. } \\
\text { Rhoades \& Eisenberger (2002) }\end{array}$ \\
\hline 3. & Job satisfaction & $\begin{array}{l}\text { An emotional attitude of } \\
\text { enjoying and loving a job. } \\
\text { Hasibuan (2009) }\end{array}$ & $\begin{array}{l}\text { 1. The job itself } \\
\text { 2. Promotion opportunities } \\
\text { 3. Supervision } \\
\text { 4. Colleagues } \\
\text { Luthan (2006) }\end{array}$ \\
\hline
\end{tabular}




\section{Results and Discussion}

To find out the regression coefficient of each independent variable and the direction of the influence on the dependent variable, the analysis of multiple regression data obtained by using SPSS program version 24 is shown in the following table:

Table 2 Multiple Linear Regression Results of Research Variables

\begin{tabular}{|c|c|c|c|c|c|c|}
\hline & \multirow{2}{*}{ Model } & \multicolumn{2}{|c|}{$\begin{array}{c}\text { Unstandardized } \\
\text { Coefficients }\end{array}$} & \multirow{2}{*}{$\begin{array}{c}\begin{array}{c}\text { Standardized } \\
\text { Coefficients }\end{array} \\
\text { Beta }\end{array}$} & \multirow{2}{*}{$\mathrm{t}$} & \multirow{2}{*}{ Sig. } \\
\hline & & $\mathrm{B}$ & $\begin{array}{l}\text { Std. } \\
\text { Error }\end{array}$ & & & \\
\hline \multirow{3}{*}{1} & (Constant) & 1.841 & 1.942 & & .948 & .346 \\
\hline & POS & -.256 & .556 & -.047 & -.460 & .647 \\
\hline & Job Satisfaction & .578 & .129 & .455 & 4.481 & .000 \\
\hline
\end{tabular}

Source :The results of primary data process (2019)

Based on the regression results seen in Table 2 above, the multiple linear regression equation in this study could be determined as follows:

Explanation:

$$
\mathrm{Y}=1,841-0,256 \mathrm{X}_{1}+0,578 \mathrm{X}_{2}+1,942
$$

Y : Organizational Citizenship Behaviour (OCB)

$\mathrm{X}_{1}$ : Perceived Organizational Support (POS)

$\mathrm{X}_{2:}$ Job satisfaction

From the processed data it was obtained that perceived organizational support (X1) had negative effect but not significant on organizational citizenship behavior $(\mathrm{Y})$ of the employees of the Regional Revenue and Asset Agency (BPAD) in West Pasaman Regency. Based on Table 20, the value of tcount was -0.460 which was smaller than t-table (1.661) with the value of sig. $0.647>0.05$. It means that Ho was accepted and Ha was rejected. So it can be concluded that the first hypothesis in this study was rejected, namely perceived organizational support did not significantly influence organizational citizenship behavior of the employees of the Regional Revenue and Asset Agency (BPAD) in West Pasaman Regency.

From the processed data, it was obtained that job satisfaction (X2) had positive and significant effect on organizational citizenship behavior (Y) of the employees of the Regional Revenue and Asset Agency (BPAD) in West Pasaman Regency. Based on Table 20, t-count value (4.481) was higher than t-table value (1.661) with sig value $0.000<0.05$. It means that Ho was rejected and Ha was accepted. So, it can be concluded that the second hypothesis in this study was accepted, namely job satisfaction had significant effect on organizational citizenship behavior $(Y)$ of the employees of the Regional Revenue and Asset Agency (BPAD) in West Pasaman Regency.

\section{Coefficient of Determination}

To find out how much the influence of independent variables (perceived organizational support and job satisfaction) on organizational citizenship behavior $(\mathrm{Y})$ of the employees of the Regional Revenue and Asset Agency (BPAD) in West Pasaman Regency was, the value of R square was found out. It can be seen in the table below.

Table 3 Model Summary

\begin{tabular}{ccccc}
\hline Model & $\mathrm{R}$ & $\begin{array}{c}\mathrm{R} \\
\text { Square }\end{array}$ & $\begin{array}{c}\text { Adjusted } \\
\mathrm{R} \text { Square }\end{array}$ & $\begin{array}{c}\text { Std. Error of } \\
\text { the Estimate }\end{array}$ \\
\hline 1 & $.461^{\mathrm{a}}$ & .212 & .192 & .58327 \\
\hline
\end{tabular}

a. Predictors: (Constant), Job Satisfaction, POS

b. Dependent Variable: OCB 
From Table 3 above, the R square value was 0.212. It indicates that the contribution of independent variables (perceived organizational support and job satisfaction) on dependent variable (organizational citizenship behavior) in this study was $21.2 \%$ while the other $78.8 \%$ was determined by other factors not examined in this study.

\section{Discussion}

\section{The First Hypothesis (the Effect of Perceived Organizational Support on Organizational Citizenship Behaviour)}

Organizational support is something that is assessed by employees as an assumption of social emotional needs, an indication of the readiness of the organization to appreciate the increase of employee work, and an indication of the tendency of an organization to prepare assistance when it is needed in order to do an effective job (Fuller et al., 2003). Robbins (2008) says that POS is the level to which employees believe that organization appreciates their contributions and cares about their welfare. When employees feel that they have been supported by the organization, the reciprocal norm of reciprocity will emerge, which individuals who are treated well by the party will feel obliged to reciprocate with a good deal.

Based on the results of processed data analyses, it can be seen that the value of sig. perceived organizational support on organizational citizenship behavior was 0.647 . Because the sig. 0.647 was bigger than 0.05 , thus the first hypothesis of this study was rejected, namely perceived organizational support did not significantly influence organizational citizenship behavior. The inconsistency of the results of this study with the theories, through a personal approach carried out by the researchers, the results showed that there was insignificant effect of POS on OCB of the BPAD employees in West Pasaman Regency, because there was mutual emulation among employees.

Although employees thought that they got support from the organization, it only made them more committed to their work and loyal to the organization, but it had not been able to encourage employees to act more than standard behavior. It was because each employee saw each other to do more and act for the organization. If they saw their seniors or friends not doing more, they themselves would not do more for the organization likewise. It is in accordance with the theory of cognitive social proposed by Bandura in Mukhid (2009) that most people learn through selective observation and remembering the behavior of others. Hergenhahn (2010) says that behavior is not imitation, whereas cognitive aspects become a consideration of why behavior arises and why it is not arised. This case is called as observational learning meaning that learning and behavior formation are not due to imitation, but there are observer's cognitive considerations for the environment.

The results of this study are not in accordance with the study conducted by I Gusti and Anak Agung (2017). Their result of the study indicated that perceived organizational support had significant effect on organizational citizenship behavior.

\section{The Second Hypothesis (the Effect of Job Satisfaction on Organizational Citizenship Behaviour)}

Organizational Citizenship Behavior can arise from various factors in the organization; one of them is caused by the job satisfaction of employees and high organizational commitment (Robbin and Judge, 2008). When employees feel satisfaction with the work they do, then the employees will work optimally in completing the work, even do some things that might be beyond their duties. Likewise, when a person has a high commitment to an organization, then he/she will do anything to develop the company because of his/her faith to the organization (Luthans, 2006).

Based on the results of processed data analyses, it was obtained that the value of sig. job satisfaction on organizational citizenship behavior was 0.000. Because the value of sig. 0.000 was smaller than 0.05 , thus the second hypothesis of this study was accepted, namely job satisfaction had significant effect on organizational citizenship behavior. It means that when employees were satisfied with their work, their OCB was a form of their appreciation for the organization which had provided satisfaction to them.

The result ot this study is in accordance with the result of a study conducted by Dana (2007) which found that there was a positive and and significant relationship between job satisfaction and 
organizational citizenship behavior and a study conducted by Roby (2011) which showed that increased job satisfaction was able to improve off-role behavior or OCBs, especially OCB-O.

\section{Conclusions}

Based on the results and discussion, the conclusions of this study are 1) Perceived Organizational Support (X1) had negative effect but not significant on Organizational Citizenship Behavior (Y) of BPAD employees in West Pasaman Regency; and 2) Job satisfaction (X2) had positive and significant effect on Organizational Citizenship Behavior (Y) of BPAD employees in West Pasaman Regency. This study shows empirical evidence that to increase the organizational citizenship behavior, it is necessary for company to improve the perceived organizational support and employee job satisfaction.

\section{References}

Arikunto, s. (2002). Metodologi Penelitian. Jakarta: PT. Rineka Cipta.

Dana, Mubasysyir Hasanbasri. (2007). Hubungan Kepuasan Kerja Dan Komitmen Organisasi Dengan Organizational Citizenship Behavior (OCB) Di Politeknik Kesehatan Banjarmasin. Working paper series, No. 2.

Eisenberger, R., Armeli, S., Rexwinkel, B., Lynch, P. D., and Rhoades,. L. (2001). Reciprocation of Perceived Organizational Support. Journal of Applied Psychology, 86 (1), 42-51.

Fuller et al. 2003. A Social Idenity Perspective on The Relationship Between Perceived Organizational Support and Organizational Commitment. Journal of Social Psychology, 143 (6), 789-791

Greenberg, Jerald dan Robert A. Baron. (2003). Behavior in Organizations, Understanding and Managing The Human Side Of Work. Massachuscets: A Division of Schuster.

Hasibuan, M. (2009). Manajemen Sumber Daya Manusia. Jakarta: Bumi Aksara.

Hergenhahn, B. R. \& Olson M. H. 2009. Theories of Learning (Teori Belajar). Jakarta: Kencana Premedia Group

I Gusti Ayu, A. Y., Harlina, N., \& Diana, R. (2011). Hubungan antara kepuasan kerja dan resiliensi dengan organizational citizenship behavior pada karyawan kantor pusat PT. BPD Bali. Jurnal psikologi Undip, 9 (1), 11-20.

I Gusti Agung Ita PErmata Sari dan Anak Agung Sagung Kartika Dewi. (2017). Pengaruh Dukungan Organizasional dan Komitmen Organisasional Terhadap OCB Karyawan F \& B di Melasti Beach Hotel Kuta. E-Jurnal Manajemen Unud, 6 (8), 4452-4480

Luthans, Fred. (2006). Perilaku Organisasi, Edisi Sepuluh. Yogyakarta: Penerbit Andi.

Mariman Darto. (2014). Peran Organizational Citizenship Behavior (OCB) Dalam Peningkatan Kinerja Individu Di Sektor Publik: Sebuah Analisis Teoritis Dan Empiris. Jurnal Borneo Administrator, 10 (1), 10-34

Mukhid, Abd. (2009). Self-Efficacy (Perspektif Teori Kognitif Sosial dan Implikasiya terhadap Pendidikan). Tadris. 4 (1), 106-122

Novira, L., \& Martono, S. (2015). Pengaruh persepsi dukungan organisasi pada perilaku kewargaan organisasional dengan kepuasan kerja sebagai variabel intervening. Management Analysis Journal, 4 (3), 180-189.

Purba, Debora Elfina ; Seniati, Ali Nina Liche . (2004). Pengaruh kepribadian dan komitmen organisasi terhadap organizational citizenship behavior. Sosial Humaniora, 8 (3), 105-111.

Rhoades,L., and Eisenberger, R.,. (2002). Perceived Organizational Support. Journal of Applied Psychology, 87 (4), 698-714.

Robbins, Stephen P and Judge, Timothy A. (2008). Perilaku Organisasi. Jakarta: Salemba empat.

Roby Sambung. (2011). Pengaruh Kepuasan Kerja Terhadap OCB-I Dan OCB-O Dengan Dukungan Organisasi Sebagai Variabel Moderating (Studi pada Universitas Palangka Raya). Analisis Manajemen, 5 (2), 77-90

Sugiyono. (2012). Metode Penelitian Administrasi. Bandung: Alfabeta. 